Biol. Stud. 2020: 14(3); 13-28 • DOI: https://doi.org/10.30970/sbi.1403.628

www.http://publications.Inu.edu.ua/journals/index.php/biology

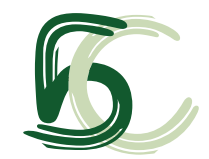

UDC: 573.3:577.29:616.8-092

\title{
PROOXIDANT-ANTIOXIDANT BALANCE IN THE METHYLOTROPHIC YEAST OGATAEA POLYMORPHA EXPOSED TO SPERMIDINE
}

\author{
N. V. Grushanyk ${ }^{\circledR 1}$, I. A. Sarai ${ }^{\circledR 1}$, O. V. Stasyk ${ }^{\circledR 2}$, O. G. Stasyk ${ }^{\circledR 1 *}$ \\ ${ }^{1}$ Ivan Franko National University of Lviv, Department of Biochemistry \\ 4, Hrushevskyi St., Lviv 79005, Ukraine \\ ${ }^{2}$ Institute of Cell Biology, NAS of Ukraine, Department of Cell Signaling \\ 14/16, Drahomanov St., Lviv 79005, Ukraine \\ ${ }^{*}$ Corresponding author e-mail: olena.stasyk@Inu.edu.ua
}

Grushanyk N.V., Sarai I.A., Stasyk O.V., Stasyk O.G. Prooxidant-antioxidant balance in the methylotrophic yeast Ogataea polymorpha exoposed to spermidine. Studia Biologica, 2020: 14(3); 13-28 • DOI: https://doi.org/10.30970/sbi.1403.628

Background. Many molecular compounds used by eukaryotic cells as antioxidant agents can directly interact with reactive oxygen/nitrogen species. Among them are polyamines - natural substances with pronounced antioxidant properties. The main polyamines are putrescine, spermidine, spermine. Spermidine is a positively charged polyamine that is synthesized from putrescine and serves a precursor of spermine. In particular, spermidine is distinguished by its anti-aging properties. When administered to several model organisms, it prolonged their lifespan and provided resistance to stress. Spermidine also limits overproduction of reactive oxigene species and reduces age-related oxidative protein damage, which accounts for its antioxidant activity.

The aim of our study was to investigate the effects of exogenous spermidine in different concentrations on the prooxidant-antioxidant balance in the methylotrophic yeast Ogataea polymorpha naturally adapted to stressful conditions such as growth on toxic methanol-containing medium and cultivation at high temperatures $\left(42-45^{\circ} \mathrm{C}\right)$.

Materials and Methods. In this work, O. polymorpha wild-type strain was used. Yeast cells were cultivated in the mineral medium with $0.1 \%$ glucose for creating stressful conditions. Spermidine was added in 1 and $2 \mathrm{mM}$ concentrations immediately before the start of yeast cultivation. Reactive oxygen species, the level of oxidative modifications of proteins and lipids, the concentration of reduced gluthatione, superoxide dismutase and catalase activities were assayed to examine the prooxidant-antioxidant state of the yeast cells.

(c) 2020 N. V. Grushanyk et al.; Published by the Ivan Franko National University of Lviv on behalf of Біологічні Студіï / Studia Biologica. This is an Open Access article distributed under the terms of the Creative Commons Attribution License (http://www.budapestopenaccessinitiative.org and Creative Commons Attribution 4.0 License), which permits unrestricted reuse, distribution, and reproduction in any medium, provided the original work is properly cited.

ISSN 1996-4536 (print) •ISSN 2311-0783 (on-line) • Біологічні Студії / Studia Biologica • 2020 • Том 14/№3 • C. 13-28 
Results. In this study, we analyzed the effects of exogenous spermidine in different concentrations on the enzymatic (superoxide dismutase and catalase activity) and nonenzymatic (reduced glutathione) antioxidant defense systems and markers of oxidative injury (products of proteins and lipids oxidation) in the methylotrophic yeast $O$. polymorpha starved for glucose. It was revealed that $1 \mathrm{mM}$ spermidine had a protective effect on O. polymorpha cells and decreased the content of products of the oxidative modification of proteins. At the same time, the superoxide dismutase and catalase activities and content of the reduced glutathione remained almost unchanged in the cells cultivated in the glucose-depleted medium with $1 \mathrm{mM}$ spermidine compared to the medium without spermidine. Adverse effects of $2 \mathrm{mM}$ spermidine (increased levels of carbonyl groups of proteins, lipid peroxidation products, disregulated superoxide dismutase and catalase activities, reduced glutathione levels, growth inhibition and cells vacuolization) were observed in the exponential growth phase of the yeast culture. During a long-term cultivation, these effects diminished, and the corresponding values approximated those of the cells grown in the control medium with the low concentration of glucose without spermidine.

Conclusions. The data suggest a concentration-dependent effect of spermidine on the physiology of $O$. polymorpha that can be used in further studies on compounds able to mitigate negative effects of the oxidative stress in this yeast and other model organisms. At $1 \mathrm{mM}$ concentration, spermidine had an apparent protective effect, whereas at the elevated $2 \mathrm{mM}$ concentration this polyamine exacerbated stress load in this yeast.

Keywords: methylotrophic yeast, Ogataea polymorpha, spermidine, oxidative stress

Registration number and Funding source. \# 0117U001226, Grant "Investigation of the mechanisms of autophagic degradation of abnormal forms of human $\alpha$-synuclein induced by low-molecular compounds in the model biosystems" and \# 0115U004200, Grant "Modeling in the yeast cells of molecular processes of Parkinson's disease and analysis of the influence of exo- and endogenous factors on the aggregation and degradation of human $\alpha$-synuclein" of Department of Cell Signaling of the Institute of Cell Biology, NAS of Ukraine.

\section{INTRODUCTION}

There are many low molecular compounds used by eukaryotic cells as antioxidant agents. Antioxidants can be both intracellularly synthetized or utilized as external compounds and can directly interact with reactive oxygen/nitrogen species. Among them are polyamines - natural substances with pronounced antioxidant properties. These compounds are aliphatic polycations ubiquitously present in all tissues and all cell types in animals and plants. Polyamines play specific and diverse roles in multiple cellular processes including cell division and differentiation, DNA and protein synthesis, gene expression, signal transduction and apoptosis $[11,26]$. They interact readily with negatively charged molecules, such as DNA, RNA and proteins, toxic aldehydes and act, therefore, as free radical (oxygene/nitrogene reactive species) scavengers $[11,26]$. Polyamines also have a chelating ability towards metal ions, thereby affecting mechanisms of oxidative stress and activity of antioxidant enzymes [21, 32] probably by regulation of the corresponding genes expression [33]. These polyamine properties extend from bacteria to yeasts and metazoans [11].

ISSN 1996-4536 (print) • ISSN 2311-0783 (on-line) • Біологічні Студії / Studia Biologica • 2020 • Том 14/№3 • C. 13-28 
The main polyamines are putrescine (Put), spermidine (Spd) and spermine (Spm) and their precursor - Agm. Polyamine metabolism and three most common polyamines, Put, Spd and Spm, were demonstrated to be involved in stress response [37]. Spd is a positively charged polyamine that is synthesized from Put and serves as a precursor of Spm. In particular, Spd is distinguished by its anti-aging properties. When administered to several model organisms, it prolonged their lifespan and provided resistance to stress. It also reduces overproduction of reactive oxigene species (ROS) and age-related oxidative protein damage, which accounts for its antioxidant activity. [12]. In the bakers' yeast Saccharomyces cerevisiae, polyamines Spd and Spm stimulated the expression of proteins essential for the effective antioxidant response. Microarray studies on Saccharomyces cerevisiae Spd- and Spm-deficient mutants revealed that exogenous Spm altered the expression of nearly 500 genes more than 2 -fold, including several oxidative stressresponse genes. [7] These mutants also required exogenous polyamines for protection against ROS, and their viability could not be rescued by overexpression of the antioxiadative stress enzyme superoxide dismutase (SOD, EC 1.15.1.1) [4, 6]. In addition, Spd induces autophagy in cultured yeast and mammalian cells, as well as in nematodes and flies. Genetic inactivation of genes essential for autophagy abolishes the life span-prolonging effect of spermidine in yeast, nematodes and flies. These fndings complement the expanding evidence that autophagy mediates cytoprotection against a variety of noxious agents and can confer longevity when induced at the whole-organism level [22].

S. cerevisiae is a well-known model organism actively used for investigation of key cell processes, including oxidative stress. However, a convenient object for the study of stress resistance in yeasts is methylotrophic yeasts - specific unicellular eukaryotic organisms able to obtain both carbon and energy needed for growth from one-Carbon compound methanol, which is oxidized to toxic formaldehyde and hydrogene peroxide. These yeasts belong to several genera: Candida, Pichia, Ogataea, Kuraishia and Komagataella [19]. All species of methylotrophic yeasts are obligate aerobes and facultative methylotrophs. However, these yeasts can readily utilize other carbohydrates, including glucose as a preferred substrate.

The methylotroph O. polymropha is a biotechnologically important yeast well known as an efficient expression platform for heterologous proteins, governed primarily by glucose-repressible promoters [16, 33, 36]. In addition, this thermotolerant yeast has been proposed as an organism for high-temperature fermentation of sugars derived from lignocellulose hydrolysates, glucose and xylose [18].

It has been found that depletion of glucose in the cultural medium causes a stressful condition for 0 . polymropha cells and induces a specific cellular response. For instance, low $0.1 \%$, versus $1 \% \mathrm{w} / \mathrm{v}$ considered as optimal, glucose concentration limits the growth of the culture [35] and causes overproduction of reactive oxygen species (ROS) in O. polymorpha cells [10]. The same situation was observed in bovine aortic endothelial cells cultivated in a low glucose-containing medium. It was shown that in these cells hypoglycemia was linked to increased ROS production. Low glucose increased mitochindrial ROS generation in the electron transfer chain that was suppressed by overexpression of Mn-SOD. A comprehensive metabolic analysis using capillary electrophoresis-mass spectrometry and oxygen consumption rate assessment showed that the pathway from fatty acids to acetyl-CoA through fatty acid oxidation was upregulated under low glucose conditions. In addition, etomoxir, a specific inhibitor of a free fatty acids transporter, decreased the low glucose-induced mitochindrial ROS production.

ISSN 1996-4536 (print) • ISSN 2311-0783 (on-line) • Біологічні Студії / Studia Biologica • 2020 • Том 14/№3 • C. 13-28 
These results suggested that low glucose increased mitochindrial ROS generation through activation of fatty acid oxidation. [13].

Similarly to other organisms, O. polymorpha cells harbor enzymatic and non-enzymatic antioxidant molecules which efficiently protect this yeast against ROS under normal conditions. However, when yeast cells suffer a prolonged or sudden acute exposure to harmful doses of ROS, their pro-survival response mechanisms may fail [17]. The failure of antioxidant defenses that impede ROS accumulation results in oxidative stress, a condition broadly defined as an imbalance between cellular prooxidants and antioxidants, in favor of the former.

The aim of this study was to investigate how exogenous polyamine spermidine affects prooxidant-antioxidant balance in O. polymorpha cells starved for glucose, and whether this compound may be potentially utilized to mitigate effects of the acute oxidative stress.

\section{MATERIALS AND METHODS}

Strains, media and microbial techniques. O. polymorpha strain used in this work was a prototrophic wild-type strain NCYC $495 \mathrm{pr}$ (leu1-1 ScLEU2). Yeast cells were cultivated on standard liquid or solid media at $37^{\circ} \mathrm{C}$ : rich medium YPD $(1 \%$ yeast extract, $2 \%$ bacto-peptone, $1 \%$ glucose $)$ or synthetic YNB medium $(0.17 \%$ yeast nitrogen base without amino acids and ammonium sulfate (YNB, Difco), $0.5 \%$ ammonium sulfate). Solid media contained agar at $2 \%$ concentration. The concentration of carbon source (glucose) was $0.1 \%\left(w \times v^{-1}\right)$, unless indicated otherwise. Cell density was determined by absorbance at $600 \mathrm{~nm}$. Yeast cells for biochemical experiments were cultivated in the media with $0.1 \%$ glucose for $15 \mathrm{~h}$, which corresponds to the exponential growth phase and $40 \mathrm{~h}$, which corresponds to the early stationary growth phase. Spermidine was supplemented into the medium at 1 and $2 \mathrm{mM}$ concentration immediately before yeast cultivation started.

Cell-free extracts preparation. Yeast cells were washed by $50 \mathrm{mM}$ potassiumphosphate buffer (PPB) (pH 6.5) with $1 \mathrm{mM} \mathrm{PMSF} \mathrm{(phenylmethylsulfonyl} \mathrm{fluoride,} \mathrm{pro-}$ tease inhibitor) to remove the components of the growth medium. The harvested cells were disrupted in $50 \mathrm{mM}$ PPB pH 6.5 with $1 \mathrm{mM}$ PMSF with $0.5 \mathrm{~mm}$ glass beads using a homogenizer $\left(1000 \mathrm{rpm}, \mathrm{r}=10 \mathrm{~cm}\right.$ ) at $4{ }^{\circ} \mathrm{C}$ during $15 \mathrm{~min}$. To prepare a cell-free extract, the homogenate was centrifuged at $15000 \mathrm{~g}$ for $20 \mathrm{~min}\left(4^{\circ} \mathrm{C}\right)$. Supernatants were transferred into fresh tubes and used for biochemical analysis.

\section{Biochemical Methods}

Superoxide Dismutase. The activity of yeast superoxide dismutase (SOD, EC 1.15.1.1) was measured by the method based on reducing nitroblue tetrazolium (NBT) using a superoxide radical, as described previously [14] with modification. The absorbance of the reaction mixture was read at $\lambda=540 \mathrm{~nm}$ against the blank probe. The results were expressed as $\%$ of inhibition of NBT reduction per $1 \mathrm{mg}$ of protein. Protein concentration was determined with Folin reagent [20].

Catalase. Catalase (CAT, EC 1.11.1.6) activity was measured by following color intensity of the complex formed by $\mathrm{H}_{2} \mathrm{O}_{2}$ with molybdenum salts [1]. The reaction mixture consisted of $0.05 \mathrm{M}$ Tris- $\mathrm{HCl}$ buffer $(\mathrm{pH} 7.8), 0.03 \%$ solution of $\mathrm{H}_{2} \mathrm{O}_{2}$, and the test sample. The reaction was stopped by adding $4 \%$ solution of ammonium molybdate after 10 min of incubation. Measurements were carried out by spectrophotometry at a wavelength of $\lambda=410 \mathrm{~nm}$. Units of CAT activity were calculated as nmole of $\mathrm{H}_{2} \mathrm{O}_{2} \times \mathrm{min}^{-1} \times \mathrm{mg}^{-1}$ of protein.

ISSN 1996-4536 (print) • ISSN 2311-0783 (on-line) • Біологічні Студії / Studia Biologica • 2020 • Том 14/№3 • C. 13-28 
Reduced Glutathione. The concentration of acid-soluble thiols including reduced glutathione (GSH) was measured in cell-free extracts by the colorimetric method with Ellman's reagent (5,5-dithio-bis-(2-nitrobenzoic) acid, DTNB) - a non-enzymatic method for determining acid-soluble thiols. SH-groups of thiols reduced DTNB to yellowcolored anionic product whose optical density was measured at $\lambda=412 \mathrm{~nm}$ by spectrophotometry [29]. A molar extinction coefficient of $13,600 \mathrm{M}^{-1} \times \mathrm{cm}^{-1}$ was used for the nitrobenzoate ion. The concentration of acid-soluble thiols, denoted as GSH concentration, was expressed in nmol per $1 \mathrm{mg}$ of protein in the cell-free extract.

Lipid Peroxidation. Thiobarbituric acid reactive substances (TBA-reactive substances) in yeast cell-free extracts were assayed via formation of a colored complex with thiobarbituric acid at a high temperature [17], and the concentration of TBARS was expressed in nmoles per $1 \mathrm{mg}$ of protein. The extinction coefficient of TBARS adduct at $532 \mathrm{~nm}$ was $155,000 \mathrm{M}^{-1} \times \mathrm{cm}^{-1}$. The reaction mixture consisted of $10 \mathrm{mM}$ phosphate buffer ( $\mathrm{pH} 7.4$ ), $1 \mathrm{mM}$ potassium permanganate, and the tested sample. $10 \mathrm{mM}$ ferrous sulfate was added to start the reaction and $20 \%$ trichloroacetic acid was added to stop the reaction.

Oxidative Modifications of Proteins. The level of oxidative modifications of proteins (OMPs) was assayed via spectrophotometric detection of aldehyde and ketone groups of aliphatic amino acid residues reacting with the 2,4-dinitrophenylhydrazine reagent to form protein-conjugated 2,4-dinitrophenylhydrazones with a characteristic absorption spectrum at $\lambda=370 \mathrm{~nm}\left(\mathrm{OMP}_{370}\right.$, represented by neutral carbonyl groups) and at $\lambda=430 \mathrm{~nm}$ $\left(\mathrm{OMP}_{430}\right.$, represented by basic carbonyl groups) [23] with a minor modification. The reaction mixture consisted of $0.85 \%$ sodium chloride, $0.1 \mathrm{M}$ 2,4-dinitrophenylhydrazine, $2 \mathrm{M}$ hydrochloric acid, $10 \%$ trichloroacetic acid, $8 \mathrm{M}$ urea solution, and the tested sample. The level of $\mathrm{OMP}_{370}$ was expressed using molar absorption coefficient of $22,000 \mathrm{M}^{-1} \times \mathrm{cm}^{-1}$, and level of $\mathrm{OMP}_{430}$ using molar absorption coefficient of $16,800 \mathrm{M}^{-1} \times \mathrm{cm}^{-1}$.

\section{Fluorescence microscopy}

ROS detection in vivo by fluorescence microscopy. ROS were detected by fluorescence microscopy using 2,7-dichlorohydrofluorescein diacetate (DCFH-DA) [8]. Cell suspension was prepared in $1 \mathrm{~mL}$ of YNB without carbon source. In parallel, a control sample containing tert-butyl hydroperoxide (TBHP) was prepared. For this, $10 \mu \mathrm{L}$ of $100 \mathrm{mM}$ TBHP was added to the suspension. $10 \mu \mathrm{L}$ of distilled water was added to the experimental sample. The samples were incubated at $37^{\circ} \mathrm{C}$ for one hour. After incubation, the cells were washed twice in liquid YNB without a carbon source, resuspended in $1 \mathrm{~mL}$ of distilled $\mathrm{H}_{2} \mathrm{O}$ and $10 \mu \mathrm{L}$ of $2 \mathrm{mM} \mathrm{DCFH}-\mathrm{DA}$ was added to the resulting suspensions. Then cells were incubated for $30 \mathrm{~min}$ in the dark at $37^{\circ} \mathrm{C}$. Images were captured on fluorescence microscope (Axio Imager A1; Carl Zeiss Microlmaging, Jena, Germany) coupled with a monochrome digital camera (Axio Cam MRm; Carl Zeiss Microlmaging) and processed using the AxioVision 4.5 (Carl Zeiss Microlmaging) and Adobe Photoshop CS5 software (Adobe Systems, Mountain View, CA). The mean fluorescence intensity per cell was calculated as the sum of intensity of fluorescence signals of the cells in the field of view (in conventional units) divided by the number of the cells in the same field of view under light microscopy. The average number of cells in the field of view was 25-30. At least five fields of view were used for the analysis.

Statistical Analysis. Statistical analysis of the results was performed using Microsoft Excel 2016. The calculation of the main statistical indicators was performed on the basis of the direct quantitative data obtained as a result of the research (arithmetic mean value $-\mathrm{M}$; arithmetic mean standard error $-\mathrm{m}$ ).

ISSN 1996-4536 (print) • ISSN 2311-0783 (on-line) • Біологічні Студії / Studia Biologica • 2020 • Том 14/№3 • C. 13-28 
To assess the probability of the difference between the statistical characteristics of the three alternative data sets (data of three independent experiments), the Student's ratio was calculated. The difference in the indications of probability $p \geq 0.95$ (significance level) was considered probable $\mathrm{P}<0.05$ after calculating $\mathrm{t}$ according to the table of Student's $t$-distribution. Designations were as follows: * $\mathrm{P}<0.05$ compared to NCYC $495 \mathrm{pr}$ (wild-type strain) grown on the medium with $0.1 \%$ glucose (control condition).

\section{RESULTS AND DISCUSSION}

As a favorite carbon substrate, glucose exerts numerous strong and well-coordinated effects on the physiological state of yeast cells. They include gene-specific regulation of transcription and mRNA stability as well as regulation at the posttranslational level, e.g., catabolite inactivation of certain enzymes [5, 9, 15, 36]. We used glucose limitation in the growth medium $(0.1 \%)$ to model conditions of glucose hypometabolism, which is associated in higher eukaryotes with increased oxidative stress, cell demage and aging $[3,13]$. We also evaluated spermidine as a potential compound modulating prooxidant-antioxidant balance and thus counteracting negative effects of glucose limitation in O. polymorpha cells.

It was found that $1 \mathrm{mM}$ Spd in the culture medium only slightly affected growth of O. polymorpha wild-type strain in the exponential and early stationary growth phase, whereas at the elevated $2 \mathrm{mM}$ concentration this negative effect became more pronounced (Fig. 1).

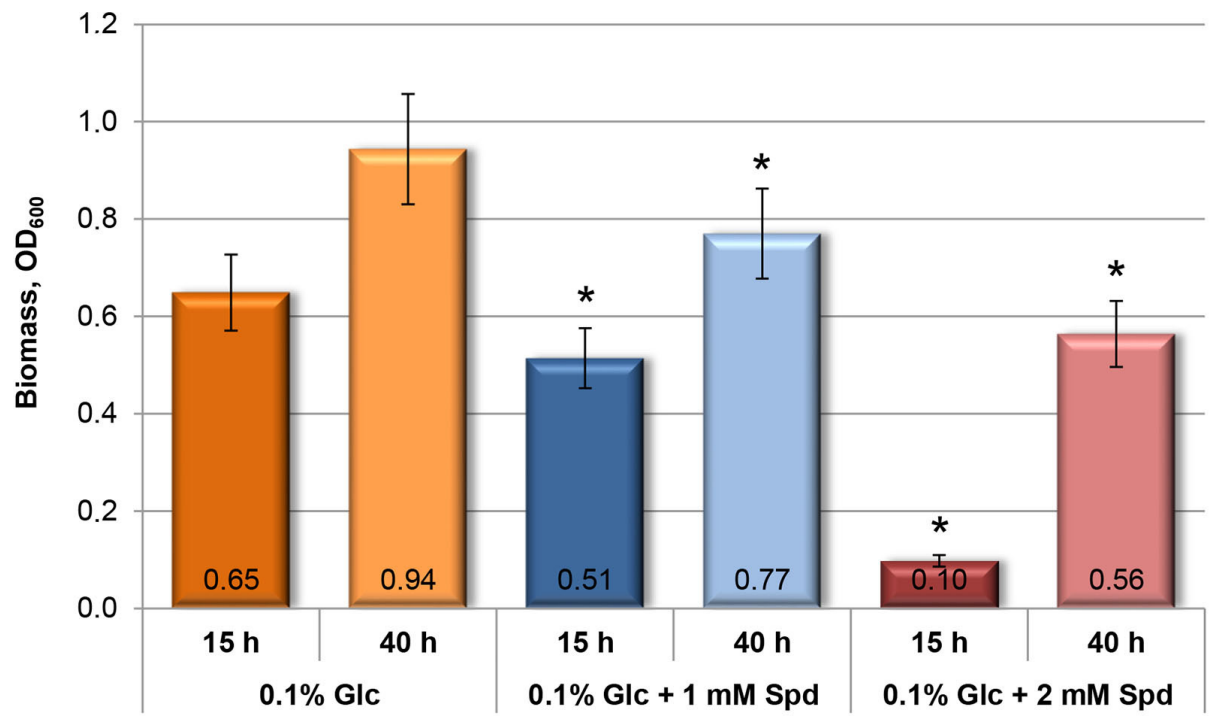

Fig. 1. Growth of O. polymorpha wild-type NCYC 495 pr strain cultivated in glucose-depleted (0.1\%) medium and different concentrations of exogenous Spd ( 1 and $2 \mathrm{mM}) .\left({ }^{*}-\mathrm{P}<0.05 ;{ }^{*}\right.$ - the difference is significant as compared to the cells grown in the medium with $0.1 \%$ glucose without Spd)

Рис. 1. Ріст штаму дикого типу О. polymorpha NCYC 495 pr під час культивування у глюкозо-дефріцитному (0,1%) середовищі з різними концентраціями екзогенного спермідину (1 і 2 мМ). (* - P < 0,05; * - різниця достовірна, порівняно з клітинами, вирощеними у середовищі з 0,1 \% глюкози без спермідину)

ISSN 1996-4536 (print) • ISSN 2311-0783 (on-line) • Біологічні Студії / Studia Biologica • 2020 • Том 14/№3 • C. 13-28 
However, this negative effect of $2 \mathrm{mM}$ Spd was transient and diminished after a long-term cultivation, probably indicating a depletion of this compound from the growth medium (data not shown).

ROS generation in 0 . polymorpha cells cultivated at different concentrations of Spd in growth media. ROSs are various derivatives of molecular oxygen formed in actively metabolizing cells, which include hydrogen peroxide, hydroxyl radicals and superoxide anions. We exploited the ability of O. polymorpha cells to transport glucose by facilitated diffusion to model the conditions for ROS overproduction. We previously observed that glucose limitation $(0.1 \%)$ in the culture medium led to the accumulation of ROS in O. polymorpha cells. Thus, cells of the wild-type strain (NCYC $495 \mathrm{pr}$ ) were pre-grown during 15 hours on mineral medium with different concentrations $(0.1,1.0$, 2.5 and $10 \%$ ) of glucose as a carbon source and 2,7-DCFH-DA was utilized for the detection of oxidative species. We found that glucose increase above $1.0 \%$ (which is assumed to represent "physiological conditions") in culture medium did not lead to the elevation of cellular ROS content, whereas glucose deprivation upon cultivation on $0.1 \%$ glucose for 15 hours did so. [10]

It was also reported that polyamines deficiency promoted ROS accumulatation in S. cerevisiae cells [6]. Our task, therefore, was to analyze how exogenous Spd at different concentrations affects the content of ROS in O. polymorpha cells depleted of glucose.

For this, yeast cells were pregrown during 15 and 40 hours on the mineral medium with different concentrations of Spd ( 1 and $2 \mathrm{mM}$ ) and $0.1 \%$ glucose as a limiting growth carbon source. 2,7-DCFH-DA was utilized for the detection of oxidative species as described in Materials and Methods (Fig. 2A). Mean fluorescence intensity per cell was digitized by GelPro software (Fig. 2B). Fluorescence microscopy data confirmed excess ROS generation in $\mathrm{O}$. polymorpha cells cultivated without Spd under our experimental conditions.

We also found that both 1 and $2 \mathrm{mM}$ Spd reduced content of ROS in the cells, especially at an early (15 hours) growth phase. After 40 hours of incubation, the proportion of oxidative species increased in the cells exposed to $1 \mathrm{mM}$ Spd. Nevertheless, ROS content in the cells incubated without polyamine was still much higher (Fig. 2A, B). This observation is in favor of Spd acting as ROS scavenger in O. polymorpha cells. It can be also assumed that the inhibiting effect of Spd on cell growth (see Fig. 1) is not due to its interference with ROS production.

In addition, we observed that especially at its higher concentration (2 mM) Spd caused morphological alterations in O. polymorpha cells increasing their volume and cell vacuolization (Fig. 2A). Formation of enlarged vacuoles is one of the main hallmarks of upinduced autophagy [1], and Spd is known to induce this process in a number of organisms [24]. Whether the same occurs in O. polymorpha and may negatively affect growth upon glucose limitation requires a separate study.

Comparative analysis of content of the oxidized proteins and lipids. Products of oxidative modifications of the biomolecules such as protein carbonyls, nitrated proteins, malondialdehyde, acrolein, isoprostanes and some others can be used as markers of oxidative and nitrosative stresses. When tyrosine and lysine residues in proteins are oxidized, the modified products are relatively stable in the cells and their accumulation may lead to the cell death [28]. Lipid peroxidation in turn yields complex products, including hydroperoxides, aldehydes, and polymeric materials which also exert cytotoxic and genotoxic effects [31]. Therefore, we addressed the question how the analyzed concentrations of Spd and intracellular ROS levels affect the cellular content of oxidized proteins and lipids under our experimental conditions.

ISSN 1996-4536 (print) • ISSN 2311-0783 (on-line) • Біологічні Студії / Studia Biologica • 2020 • Том 14/№3 • C. 13-28 
$\boldsymbol{A}$

$0.1 \%$ Glc

$+1 \mathrm{mM}$ Spd

$0.1 \%$ Glc

$+2 \mathrm{mM}$ Spd

B
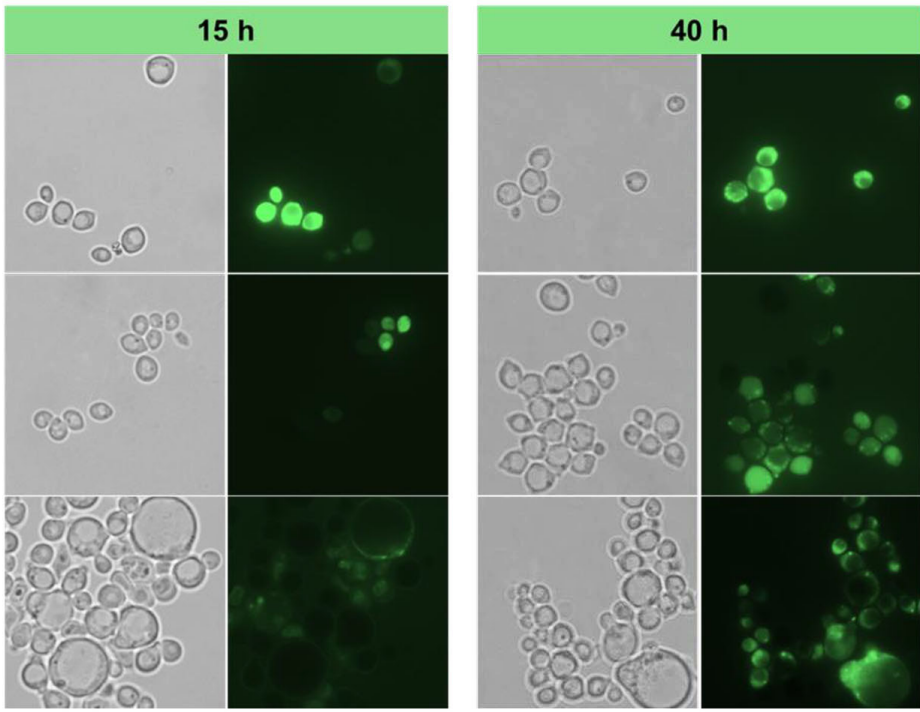

Average fluorescence intensity per cell

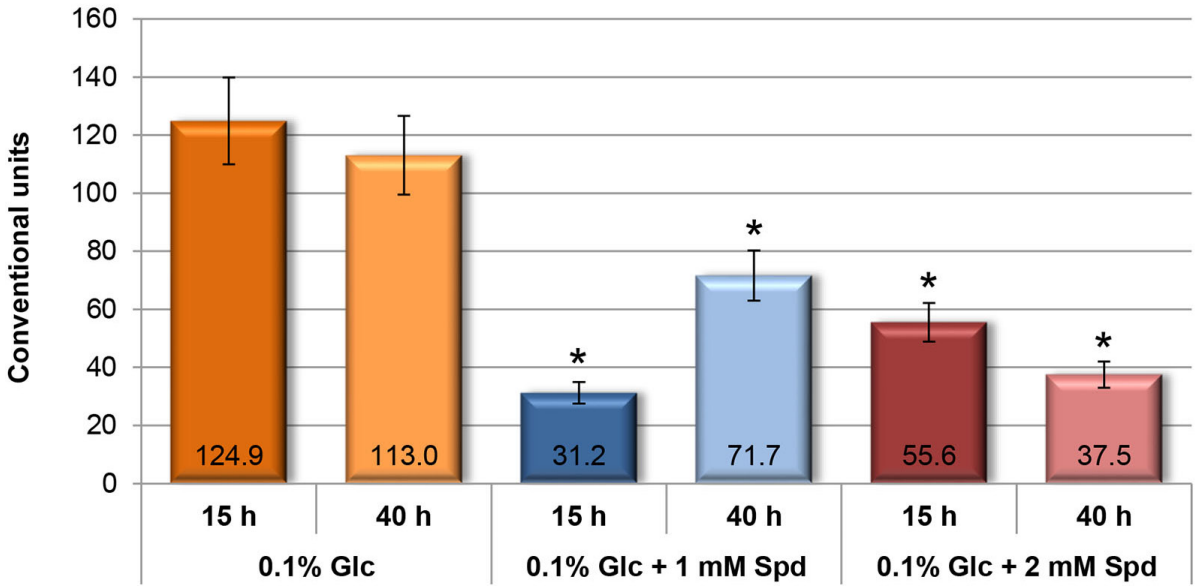

Fig. 2. In vivo ROS detection in cells of O. polymorpha: $\boldsymbol{A}$ - fluorescence images of 0 . polymorpha cells treated with DCFH-DA as described in Materials and Methods; $\boldsymbol{B}$ - average fluorescence intensity per cell digitized by GelPro software. $\left({ }^{*}-\mathrm{P}<0.05 ;{ }^{*}-\right.$ the difference is significant as compared to the cells grown in the medium with $0.1 \%$ glucose without Spd)

Рис. 2. In vivo детекція АФК у клітинах O. polymorpha: $\boldsymbol{A}$ - фрлуоресцентні мікрофротографії клітин O. polymorpha, оброблених DCFH-DA, як описано у Матеріалах і Методах; $\boldsymbol{B}$ - середня інтенсивність фллуоресценції на одну клітину в полі зору, оцифрована за допомогою програмного забезпечення GelPro. (* - P $<0,05$; * - різниця достовірна, порівняно з клітинами, вирощеними у середовищі з $0,1 \%$ глюкози без спермідину)

We observed a decreased level of protein carbonyls in the cells treated with $1 \mathrm{mM}$ Spd in comparison to those incubated in polyamine-free medium after a short $(15 \mathrm{~h})$ or prolonged (40 h) treatment (Fig. 3A, B). However, 2 mM Spd caused an opposite effect significantly increasing the oxidized proteins level. Apparently, these protein modifications did not strictly correlate with the measured intracellular ROS values (see Fig. 2).

ISSN 1996-4536 (print) • ISSN 2311-0783 (on-line) • Біологічні Студії / Studia Biologica • 2020 • Том 14/№3 • C. 13-28 

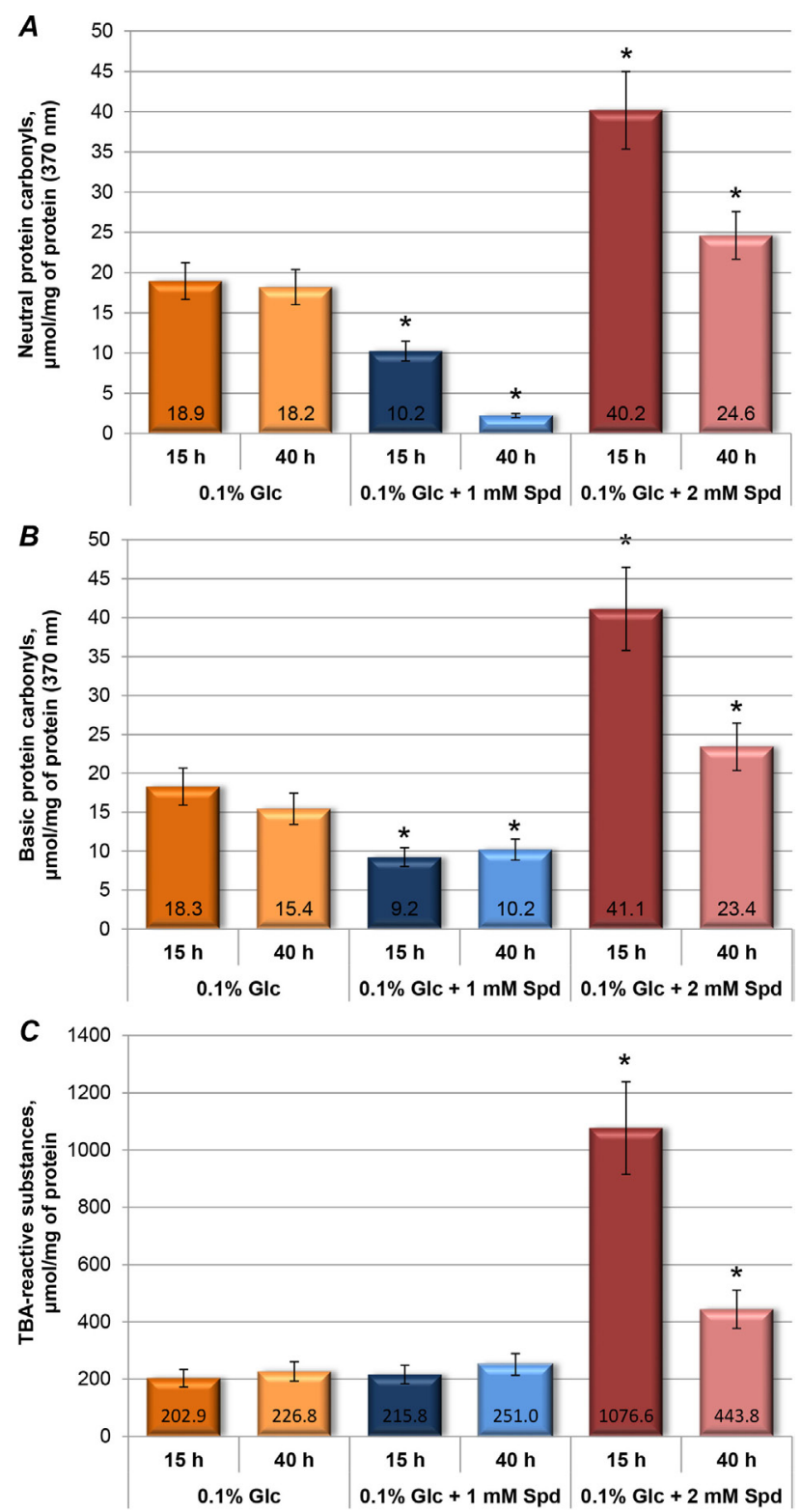

Fig. 3. Content of the oxidized proteins and lipids in O. polymorpha cells depleted of glucose and exposed to Spd: $\boldsymbol{A}$ - content of neutral protein carbonyls $(\lambda=370 \mathrm{~nm}) ; \boldsymbol{B}$ - content of basic protein carbonyls $(\lambda=430 \mathrm{~nm}) ; C$ - content of TBA-reactive substances. Assays were conducted as described in Materials and Methods $\left({ }^{*}-\mathrm{P}<0.05 ;{ }^{*}-\right.$ the difference is significant as compared to the cells grown in the medium with $0.1 \%$ glucose without Spd)

Рис. 3. Вміст продуктів окиснення білків і ліпідів у клітинах О. polymorpha, культивованих у середовищі з дефіцитом глюкози та різними концентраціями спермідину: $\boldsymbol{A}$ - вміст карбонільних груп білків нейтрального характеру $(\lambda=370$ нм); $\boldsymbol{B}$ - вміст карбонільних груп білків основного характеру $(\lambda=430$ нм); $\boldsymbol{C}$ - вміст ТБК-позитивних продуктів. Визначення відповідних показників описано у розділі Матеріали та Методи ( ${ }^{*}-\mathrm{P}<0,05 ;{ }^{*}$ - різниця достовірна, порівняно з клітинами, вирощеними у середовищі з 0,1\% глюкози без спермідину) 
The same concerns the measured intracellular levels of oxidized lipid forms (TBAreactive substances, Fig. 3 C). $2 \mathrm{mM}$ Spd significantly increased their content, while $1 \mathrm{mM}$ polyamine did not produce a visible effect. It should be noted, however, that an increased cellular content of TBA-reactive substances usually indicates an excessive ROS production [17]. Apparently, the situation in O. polymorpha and effects of exogenous Spd are more complex.

Effect of Spd on O. polymorpha antioxidative defense systems. If increased above the physiological limits free radicals, including ROS are removed by cellular antioxidant defenses that involve enzymatic (superoxide dismutase (SOD), catalase (CAT) and glutathione peroxidase (GPx)), or non-enzymatic components, such as glutathione (GSH) $[3,10,28]$. In our previouse study, we revealed that SOD and CAT activities were highest in the 0 . polymorpha cells cultured under glucose limitation $(0.1 \%$ glucose in growth medium) that evokes ROS overproduction, whereas in the cells grown on the media with elevated glucose concentrations (higher then $1 \%$ ), activities of these enzymes were significantly lower and did not exceed the values of the wild-type cells cultured under physiological conditions (1 \% glucose-containing medium) (see Fig. 1, 2). [10]

In the present study, we observed that $1 \mathrm{mM}$ Spd had a minimal effect on SOD or CAT activities as well as the intracellular level of the reduced GSH (Fig. 4). However, the effects of the elevated $2 \mathrm{mM}$ Spd were disctinct and well pronounced. Although SOD and CAT are functional partner enzymes, $2 \mathrm{mM}$ Spd had an opposite effect on their activities in the glucose-depleted O. polymorpha cells. It apparently inhibited CAT in the early exponential growth phase, but upinduced its activity after $40 \mathrm{~h}$ (stationary phase), as compared to cells exposed to $1 \mathrm{mM} \mathrm{Spd}$ and control cells incubated without polyamine (Fig. 4A). At the same time, $2 \mathrm{mM}$ Spd profoundly elevated SOD activity in the early $(15 \mathrm{~h})$, but not later $(40 \mathrm{~h})$, growth phase (Fig. $4 \mathbf{B})$. It is known that Spd can regulate SOD at the transcriptional level [6]. In turn, the modulation of CAT activity by $2 \mathrm{mM}$ Spd may be related to its own catabolism that involves hydrogen peroxide production [25].

It remains to be investigated how the observed elevated GSH levels (Fig. 4C) in the cells exposed to $2 \mathrm{mM} \mathrm{Spd}$ for $15 \mathrm{~h}$ are mechanistically or regulatory connected with the oxidative forms of proteins and lipids (Fig. 3) and intracellular ROS levels (Fig. 2).

In our previous work, we noted that changes in the intracellular GSH levels in O. polymorpha wild type strain generally resembled those in SOD activity. The level of GSH increased by $35 \%$ in the wild type cells grown on glucose-deficient medium compared to the cells grown under physiological conditions $(1.0 \%$ glucose in the culture medium). The GSH content decreased with increasing glucose concentration in the medium similarly to SOD activity [10]

In this work, we showed that $1 \mathrm{mM}$ Spd did not effect GSH content in the yeast cells as compared to the cells grown on the medium with $0.1 \%$ glucose without this polyamine. At the same time, $2 \mathrm{mM}$ Spd promoted increase in GSH in 15 hours' culture of O. polymorpha (Fig. 4C).

It is of note that a drop in GSH level in 40 hours' culture positively correlated with a decrease in the content of products of protein and lipid oxidation (Fig. 3). These changes may be tentatively caused by a gradual Spd depletion from the medium.

ISSN 1996-4536 (print) • ISSN 2311-0783 (on-line) • Біологічні Студії / Studia Biologica • 2020 • Том 14/№3 • C. 13-28 

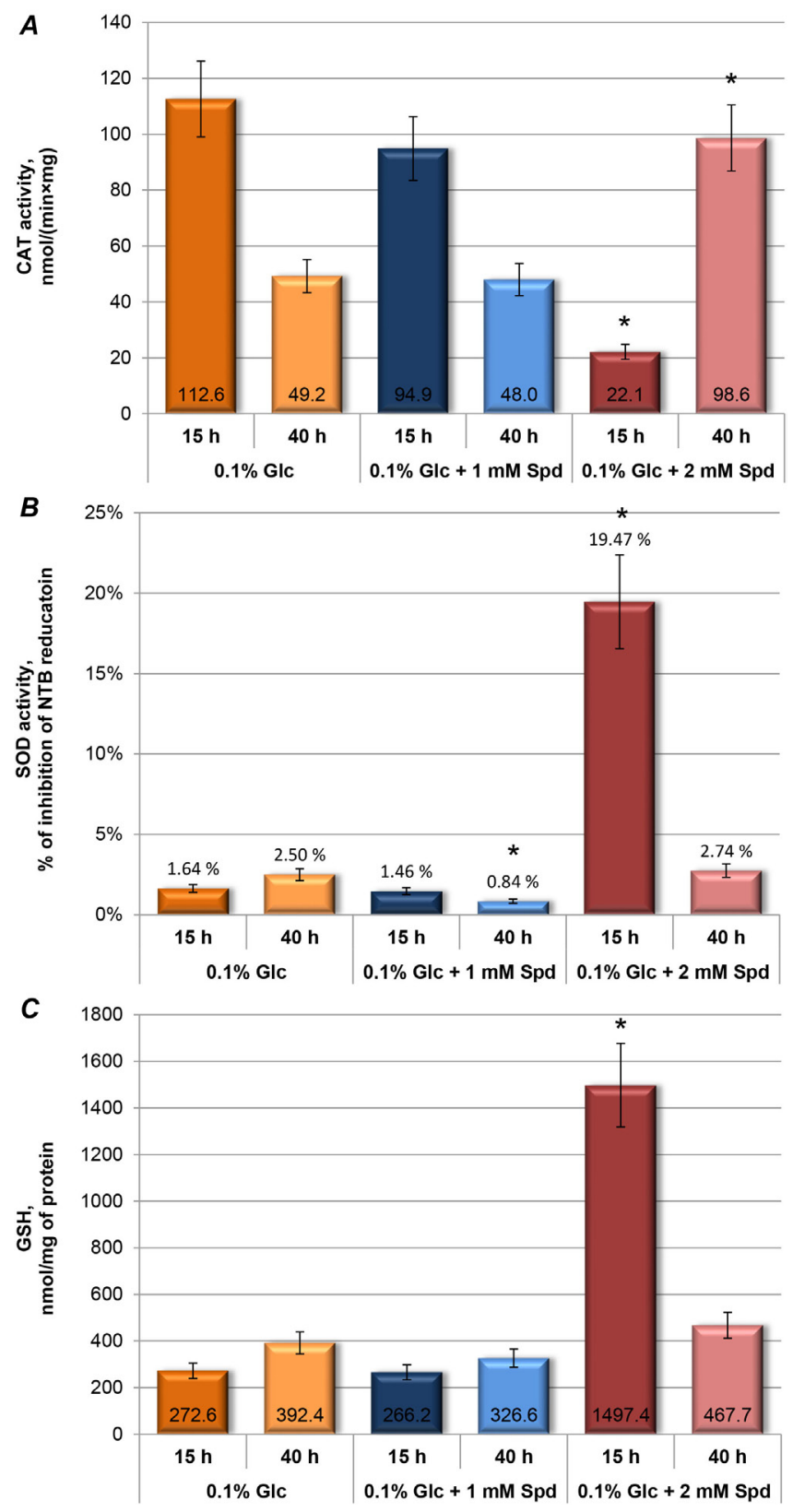

Fig. 4. Components of the antioxidant defense system in O. polymorpha: $\boldsymbol{A}$ - activity of catalase (CAT); $\boldsymbol{B}-$ activity of superoxide dismutase (SOD); $\boldsymbol{C}$ - content of the reduced gluthatione (GSH). Yeast cells were grown in the medium with $0.1 \%$ glucose with or without Spd. $\left({ }^{*}-\mathrm{P}<0.05,{ }^{*}-\right.$ the difference is significant as compared to the cells grown in the medium with $0.1 \%$ glucose without Spd)

Рис. 4. Компоненти антиоксидантної системи захисту клітин О. polymorpha: $\mathbf{A}$ - активність каталази (CAT); $\boldsymbol{B}$ - активність супероксиддисмутази (SOD); $\boldsymbol{C}$ - вміст відновленого глутатіону (GSH). Клітини дріжджів вирощували у середовищі з 0,1 \% глюкози із додаванням чи без екзогенного спермідину (* $-\mathrm{P}<0,05$; * - різниця достовірна, порівняно $з$ клітинами, вирощеними у середовищі з $0,1 \%$ глюкози без спермідину) 


\section{CONCLUSIONS}

We analyzed the effects of different concentrations of exogenous Spd (1 and $2 \mathrm{mM}$ ) in the background of glucose deprivation on prooxidant-antioxidant balance in the cells of the methylotrophic yeast 0 . polymorpha, and whether this polyamine can counteract intracellular oxidative stress. Indeed, we observed a concentration-dependent effect of Spd on O. polymorpha physiology. It can be also concluded that Spd at $1 \mathrm{mM}$ concentration had a lagerly protective effect on $O$. polymorpha cells by decreasing ROS content evoked by the stress of glucose limitation. Thus, upon addition of $1 \mathrm{mM} \mathrm{Spd}$ to the glucose-limited culture medium, the antioxidant defense system dominates in the yeast cells. However, when elevated to $2 \mathrm{mM}$ concentration, Spd produced a multifaceted complex effect inhibiting growth and dramatically elevating cellular contect of the oxidized froms of proteins and lipids, and most probably upinducing autophagy. This effect, however, diminished with incubation time and was not due to the accumulation of free radical species that were probably counterbalanced by the observed increased GSH content. Therefore, $2 \mathrm{mM}$ Spd apparently shifts the prooxidant-antioxidant balance towards the domination of prooxidants in O. polymorpha cells.

The observed apparent positive effect of a lower $(1 \mathrm{mM})$ concentration of Spd on the prooxidant-antioxidant balance of $O$. polymorpha cells can be used in further studies with this yeast model on possible correction of pathological conditions associated with different forms of oxidative stress. For instance, it can be examined whether in addition to the oxidative state of a cell, lower concentrations of Spd, or of its mixture with other polyamines, such as spermine or agmatine, will affect cellular life span, prosurvival autophagy or apopotosis.

\section{FUNDING}

The experiments described in this article were partially supported by the project of the Department of Biochemistry, Faculty of Biology, Ivan Franko National University of Lviv "Investigation of the mechanisms of autophagic degradation of abnormal forms of human $\alpha$-synuclein induced by low-molecular compounds in the model biosystems" (\# 0117U001226) and by the grant "Modeling in yeast cells of the molecular processes of Parkinson's disease and analysis of the effect of exo- and endogenous factors on the processes of aggregation and degradation of human $\alpha$-synuclein" of the Department of Cell Signaling of the Institute of Cell Biology, NAS of Ukraine (\# 0115U004200).

\section{COMPLIANCE WITH ETHICAL STANDARDS}

Conflict of Interest: The authors declare that the research was conducted in the absence of any commercial or financial relationships that could be construed as a potential conflict of interest.

Animal Rights: This article does not contain any studies with animal subjects performed by the any of the authors.

1. Aebi H. Catalase in vitro. Methods Enzymol., 1984; 105: 121-126.

Crossref $\bullet$ PubMed $\bullet$ Google Scholar

2. Armstrong J. Yeast vacuoles: more than a model lysosome. Trends Cell Biol., 2010; 20(10): 580-585.

Crossref $\bullet$ PubMed $\bullet$ Google Scholar

3. Avery S.V. Molecular targets of oxidative stress. Biochem J, 2011; 434(2): 201-210.

Crossref $\bullet$ PubMed $\bullet$ Google Scholar

ISSN 1996-4536 (print) • ISSN 2311-0783 (on-line) • Біологічні Студії / Studia Biologica • 2020 • Том 14/№3 • C. 13-28 
4. Balasundaram D., Tabor C.W., Tabor H. Oxygen toxicity in a polyamine-depleted spe2 delta mutant of Saccharomyces cerevisiae. Proc. Natl. Acad. Sci. USA, 1993; 90(10): 4693-4697. Crossref $\bullet$ PubMed $\bullet$ Google Scholar

5. Belinchón M.M., Gancedo J.M. Glucose controls multiple processes in Saccharomyces cerevisiae through diverse combinations of signaling pathways. FEMS Yeast Res., 2007; 7(6): 808-818.

Crossref $\bullet$ PubMed $\bullet$ Google Scholar

6. Chattopadhyay M.K., Tabor C.W., Tabor H. Polyamine deficiency leads to accumulation of reactive oxygen species in a spe2 $\Delta$ mutant of Saccharomyces cerevisiae. Yeast, 2006; 23(10): 751-761.

Crossref • PubMed • Google Scholar

7. Chattopadhyay M.K., Chen W., Poy G., Cam M., Stiles D., Tabor H. Microarray studies on the genes responsive to the addition of spermidine or spermine to a Saccharomyces cerevisiae spermidine synthase mutant. Yeast, 2009; 26(10): 531-544.

Crossref $\bullet$ PubMed $\bullet$ Google Scholar

8. Dikalov S.I., Harrison D.G. Methods for detection of mitochondrial and cellular reactive oxygen species. Antioxid. Redox Signal., 2014; 20(2): 372-382.

Crossref $\bullet$ PubMed $\bullet$ Google Scholar

9. Geladé R., Van de Velde S., Van Dijck P., Thevelein J.M. Multi-level response of the yeast genome to glucose. Genome Biol., 2003, 4(11): 233.

Crossref $\bullet$ PubMed $\bullet$ Google Scholar

10. Hrushanyk N.V., Stasyk O.V., Stasyk O.G. Oxidative stress regulation in the yeast Ogataea polymorpha producer of human $\alpha$-synuclein. Ukr. Bioch. J., 2020; 92(5): 120-133.

11. Handa A.K., Fatima T., Mattoo A.K. Polyamines: bio-molecules with diverse functions in plant and human health and disease. Front. Chem., 2018; 6: 10.

Crossref $\bullet$ PubMed $\bullet$ Google Scholar

12. Jeong J.W., Cha H.J., Han M.H. et al. Spermidine protects against oxidative stress in inflammation models using macrophages and zebrafish. Biomol. Ther. (Seoul), 2018; 26(2): 146-156. Crossref $\bullet$ PubMed $\bullet$ Google Scholar

13. Kajihara N., Kukidome D., Sada K. et al. Low glucose induces mitochondrial reactive oxygen species via fatty acid oxidation in bovine aortic endothelial cells. J. Diabetes Investig., 2017; 8(6): 750-761.

Crossref $\bullet$ PubMed $\bullet$ Google Scholar

14. Kakkar P., Das B., Viswanathan P.N. A modified spectrophotometric assay of superoxide dismutase. Indian. J. Biochem. Biophys., 1984; 21(2): 130-2.

PubMed • Google Scholar

15. Kim J.H., Brachet V., Moriya H., Johnston M. Integration of transcriptional and posttranslational regulation in a glucose signal transduction pathway in Saccharomyces cerevisiae. Eukaryotic Cell, 2006; 5(1): 167-173.

Crossref $\bullet$ PubMed $\bullet$ Google Scholar

16. Krasovska O.S., Stasyk O.G., Nahorny V.O., Stasyk O.V., Granovski N., Kordium V.A., Vozianov O.F., Sibirny A.A. Glucose-induced production of recombinant proteins in Hansenula polymorpha mutants deficient in catabolite repression. Biotechnol. Bioeng., 2007; 97: 858-870.

Crossref $\bullet$ PubMed $\bullet$ Google Scholar

17. Krasowska A., Lukaszewicz M., Oświęcimska M., Witek S., Sigler K. Spontaneous and radical-induced plasma membrane lipid peroxidation in differently oxidant-sensitive yeast species and its suppression by antioxidants. Folia Microbiol. (Praha), 2000; 45(6): 509-514. Crossref $\bullet$ PubMed $\bullet$ Google Scholar

18. Kurylenko O.O., Ruchala J., Vasylyshyn R.V., Stasyk O.V., Dmytruk O.V., Dmytruk K.V., Sibirny A.A. Peroxisomes and peroxisomal transketolase and transaldolase enzymes are essential for xylose alcoholic fermentation by the methylotrophic thermotolerant yeast, Ogataea (Hansenula) polymorpha. Biotechnol. Biofuels., 2018; 11: 197.

Crossref $\bullet$ PubMed $\bullet$ Google Scholar

ISSN 1996-4536 (print) • ISSN 2311-0783 (on-line) • Біологічні Студії / Studia Biologica • 2020 • Том 14/№3 • С. 13-28 
19. Limtong S., Srisuk N., Yongmanitchai W., Yurimoto H., Nakase T. Ogataea chonburiensis sp. nov. and Ogataea nakhonphanomensis sp. nov., thermotolerant, methylotrophic yeast species isolated in Thailand, and transfer of Pichia siamensis and Pichia thermomethanolica to the genus Ogataea. Int. J. System. Evol. Microbiol., 2008; 58(1): 302-307.

Crossref $\bullet$ PubMed $\bullet$ Google Scholar

20. Lowry O.H., Rosebrough N.J., Farr A.L., Randall R.J. Protein measurement with the Folin phenol reagent. J. Biol. Chem., 1951; 193(1): 265-275.

PubMed • Google Scholar

21. LØVaas E. Antioxidative and metal-chelating effects of polyamines. Adv. Pharmacol, 1997; 38: 119-149.

Crossref $\bullet$ Google Scholar

22. Madeo F., Eisenberg T., Büttner S., Ruckenstuhl C., Kroemer G. Spermidine: a novel autophagy inducer and longevity elixir. Autophagy, 2010; 6(1): 160-162.

Crossref $\bullet$ PubMed $\bullet$ Google Scholar

23. Meschishen I.F. The method of determining the oxidative modification of plasma proteins. Bukovynsky Med. J., 1998; 2: 156-158.

24. Minois $N$. Molecular basis of the "anti-aging" effect of spermidine and other natural polyamines - a mini-review. Geront., 2014; 60(4): 319-326.

Crossref $\bullet$ PubMed $\bullet$ Google Scholar

25. Murray Stewart T., Dunston T.T., Woster P.M., Casero R.A. Jr. Polyamine catabolism and oxidative damage. J. Biol. Chem., 2018; 293(48): 18736-18745.

Crossref $\bullet$ PubMed $\bullet$ Google Scholar

26. Park S.J., Kwak M.K., Kang S.O. Schiff bases of putrescine with methylglyoxal protect from cellular damage caused by accumulation of methylglyoxal and reactive oxygen species in Dictyostelium discoideum. Int. J. Biochem. Cell Biol., 2017; 86: 54-66.

Crossref $\bullet$ PubMed $\bullet$ Google Scholar

27. Pegg A.E. Functions of polyamines in mammals. J. Biol. Chem., 2016; 291(29): 14904-14912. Crossref $\bullet$ PubMed $\bullet$ Google Scholar

28. Phaniendra A., Jestadi D.B., Periyasamy L. Free radicals: properties, sources, targets, and their implication in various diseases. Indian J. Clin. Biochem., 2015; 30(1):-11-26.

Crossref $\bullet$ PubMed $\bullet$ Google Scholar

29. Rahman I., Kode A., Biswas S.K. Assay for quantitative determination of glutathione and glutathione disulfide levels using enzymatic recycling method. Nat. Protoc., 2006; 1(6): 3159-3165.

Crossref $\bullet$ PubMed $\bullet$ Google Scholar

30. Raza H., John A., Howarth F.C. Increased oxidative stress and mitochondrial dysfunction in zucker diabetic rat liver and brain. Cell Physiol. Biochem., 2015; 35(3): 1241-51.

Crossref • PubMed • Google Scholar

31. Reed T.T. Lipid peroxidation and neurodegenerative disease. Free Radic. Biol. Med., 2011; 51(7): 1302-1319.

Crossref $\bullet$ PubMed $\bullet$ Google Scholar

32. Rider J.E., Hacker A., Mackintosh C.A., Pegg A.E., Woster P.M., Casero R.A.Jr. Spermine and spermidine mediate protection against oxidative damage caused by hydrogen peroxide.

Amino Acids, 2007; 33 (2): 231-240.

Crossref $\bullet$ PubMed $\bullet$ Google Scholar

33. Saikat P., Aryadeep R. Seed priming with spermine and spermidine regulates the expression of diverse groups of abiotic stress-responsive genes during salinity stress in the seedlings of indica rice varieties. Plant Gene, 2017; 11: 124-132.

Crossref $\bullet$ Google Scholar

34. Stasyk O.V. Methylotrophic yeasts as producers of recombinant proteins. Biotechnology of yeasts and filamentous fungi / Ed. A.A. Sybirny. Springer International Publishing AG, 2017. P. 325-350.

Crossref $\bullet$ Google Scholar

ISSN 1996-4536 (print) • ISSN 2311-0783 (on-line) • Біологічні Студії / Studia Biologica • 2020 • Том 14/№3 • C. 13-28 
35. Stasyk O.G., Romanyshyn A., Denega I., Klymyshyn N., Stasyk O.V. Influence of different concentrations of extracellular glucose on cytotoxicity of human $\alpha$-synuclein in model strains of the yeast Hansenula polymorpha. Visnyk Lviv Univ. Ser. Biol., 2016; 73: 85-95. (In Ukrainian) Google Scholar

36. Stasyk O.G., Stasyk O.V. Glucose Sensing and Regulation in Yeasts. In book: Non-conventional Yeasts: from Basic Research to Application / Ed. by A.A. Sybirny. Springer International Publishing, 2019. P. 477-519.

Crossref $\bullet$ Google Scholar

37. Valdés-Santiago L., Ruiz-Herrera J. Stress and polyamine metabolism in fungi. Front Chem., 2014; $1: 42$.

Crossref • PubMed • Google Scholar

\title{
ПРООКСИДАНТНО-АНТИОКСИДАНТНА РІВНОВАГА В МЕТИЛОТРОФНИХ ДРІЖДЖІВ OGATAEA POLYMORPHA ЗА ВПЛИВУ СПЕРМІДИНУ
}

\author{
Н. В. Грушаник', І. А. Сарай', О. В. Стасик², О. Г. Стасик \\ 1 Львівський національний університет імені Івана Франка \\ вул. Грушевського, 4, Львів 79005, Україна \\ 2 Інститут біології клітини, НАН України, вул. Драгоманова, 14/16, Львів 79005, Україна \\ *Кореспондуючий автор: e-mail: olena.stasyk@Inu.edu.ua
}

Вступ. Багато низькомолекулярних сполук, які клітини використовують як антиоксиданти, можуть безпосередньо взаємодіяти з активними формами кисню/нітрогену. Серед них поліаміни, - природні речовини з яскраво вираженими антиоксидантними властивостями. Основними поліамінами $є$ путресцин, спермідин, спермін. Спермідин - позитивно заряджений поліамін, який синтезується з путресцину і слугує попередником сперміну. Під час застосування спермідину на кількох модельних організмах було виявлено його антивікові властивості, здатність продовжувати життя та забезпечувати стійкість до стресу. Спермідин також зменшує окисне пошкодження білків, асоційоване з віком, і надпродукцію активних форм кисню, що обумовлює його антиоксидантну активність. Метою дослідження було проаналізувати вплив різних концентрацій екзогенного спермідину на баланс прооксидантів і антиоксидантів у метилотрофнних дріжджах Ogataea polymorpha, природно пристосованих до стресових умов існування, таких як ріст на середовищі, що містить токсичний метанол, і культивування за високих температур $\left(42-45^{\circ} \mathrm{C}\right)$.

Матеріали та методи. У цій роботі використано штам дикого типу О. polymorpha. Для створення стресових умов клітини дріжджів культивували в мінеральному середовищі з 0,1 \% глюкози. Спермідин додавали в концентраціях 1 і 2 мМ безпосередньо перед початком вирощування культури дріжджів. Для дослідження прооксидантно-антиоксидантного стану клітин було проведено визначення активних форм кисню in vivo, рівня окисних модифрікацій білків і ліпідів, концентрації відновленого глутатіону, активностей супероксиддисмутази та каталази.

Результати. У дослідженні проаналізовано вплив різних концентрацій екзогенного спермідину на ферментативну (активність супероксиддисмутази і каталази) та неферментативну (відновлений глутатіон) ланки системи антиоксидантного захисту та маркери окисного пошкодження клітин (продукти окиснення білків і ліпідів)

ISSN 1996-4536 (print) • ISSN 2311-0783 (on-line) • Біологічні Студії / Studia Biologica • 2020 • Том 14/№3 • C. 13-28 
у метилотрофних дріжджів О. polymorpha за умов дефіциту глюкози. Виявлено, що 1 мМ спермідин мав захисний ефект у клітинах O. polymorpha, зменшуючи вміст продуктів окисної модифікації білків. Водночас активність супероксиддисмутази та каталази та вміст відновленого глутатіону залишалися майже незмінними, порівняно зі середовищем без спермідину. Побічні ефекти 2 мМ спермідину (підвищений вміст карбонільних груп білків, продуктів перекисного окиснення ліпідів, змінений рівень активності супероксиддисмутази та каталази, підвищення пулу відновленого глутатіону, інгібування росту та вакуолізація клітин) спостерігали у фразі експоненційного росту культури дріжджів. Під час тривалого культивування ці ефекти зменшувалися, а значення досліджуваних показників наближалися до значень показників клітин, вирощених у середовищі з низькою концентрацією глюкози без спермідину.

Висновки. Отримані дані свідчать про залежний від концентрації вплив спермідину на фізіологію O. polymorpha, який може бути використаний для подальшого вивчення сполук, здатних пом'якшувати негативний вплив оксидативного стресу в цих дріжджах та інших модельних організмах. У концентрації 1 мМ спермідин чинив помітний захисний ефект, тоді як за підвищеної 2 мМ концентрації цей поліамін посилював стрес у клітинах дріжджів.

Ключові слова: метилотрофні дріжджі, Ogataea polymorpha, спермідин, оксидативний стрес 